\title{
Vassoura, balcão, escritório e rua: a caixeiragem como carreira
}

Broom, Balcony, Office and Street:

the Clerk's Job as Career

\section{Bruno Augusto Dornelas}

\section{Câmara}

Doutorando em História

pela Universidade Federal de

Pernambuco

\section{Resumo}

0 presente artigo enfoca a inserção dos caixeiros portugueses no comércio urbano, tendo como pano de fundo o funcionamento interno das casas de comércio a retalho e de grosso trato do Recife. Conhecendo um pouco a vivência desses trabalhadores imigrantes e a acirrada disputa pelas restritas vagas no mercado de serviços da cidade, podemos entender em parte as manifestações antilusitanas que perturbaram a vida social e política da Província de Pernambuco, durante os anos quarenta do século XIX.

\section{Abstract}

This article focuses on the insertion of the Portuguese clerks in the urban commerce, having as scenery the internal functioning of the retail and wholesale trade in Recife. Through the experience of these immigrants in a town where there were few jobs avallable, we can understand better the Anti-Portuguese riots that disturbed the social life and politics of the Province of Pernambuco, during the 1840s.

\section{Palavras-chave}

Império do Brasil, Pernambuco, imigrantes, comércio, grupos sociais, conflitos

\section{Keywords}

Brazilian Empire, Pernambuco, immigrants, trade, social groups, conflicts 
Representação lida na Sessão Ordinária da Assembléia Provincial de Pernambuco no dia 27 de junho de 1848. APEJE (Arquivo Público Estadual Jordão Emereciano), 0 Lidador, 30.06.1848, n. 293; LEPEH-UFPE (Laboratório de Pesquisa e Ensino de História da Universidade Federal de Pernambuco), Diário de Pernambuco, 01.07.1848, n. 143
Os anos que antecederam a Insurreição Praieira são marcados por intensas agitações no cenário político do Império, em especial na Província de Pernambuco. Entre 1842 e 1849, uma ferrenha disputa entre conservadores e liberais marcaria definitivamente a história da província durante 0 Segundo Reinado. Porém, longe das coxias dos poder, as agitações políticas do momento foram sentidas pela população livre da cidade do Recife de diferentes maneiras. Nas ruas, tabernas e botequins da cidade, uma boa parte da população vivenciava esse período em meio às angustias do dia-adia. 0 problema da sobrevivência diária, da reprodução da vida material e, principalmente, da desvalorização social do indivíduo estavam presentes no cotidiano da gente mais pobre do lugar.

0 protesto popular daqueles anos chegou na forma de intensas manifestações de rua, em que a principal vítima era a comunidade portuguesa estabelecida no comércio da cidade. Durante os anos quarenta ocorreram cerca de sete mata-marinheiros. Contudo, a mais intensa manifestação antilusitana já vista no Recife ocorreu entre os dias 26 e 27 de junho de 1848. A capital da província viveu momentos de intensa agitação. Ocorreram saques a lojas e muita pancadaria. Pelo menos cinco portugueses foram assassinados e cerca de quarenta ficaram feridos, todos vitimados pela violência nativista. Sabe-se que o tumulto teve um ponto de partida: uma confusa briga entre um estudante brasileiro do Liceu e um caixeiro português de um armazém de carne seca. E teve um aparente fim: uma multidão marchando em direção a Assembléia Provincial exigindo, através de uma petição, a nacionalização do comércio a retalho e a expulsão dos portugueses solteiros, num prazo de 15 dias.?

Podemos afirmar que um número significativo desses "portugueses solteiros", aos quais se referia a "multidão" era, na sua maioria, formado de caixeiros do comércio. 0 presente artigo se propõe a lançar uma luz sobre essa categoria profissional, tendo como pano de fundo o funcionamento interno das casas de comércio do Recife. Realizando um estudo pontual desses caixeiros de comércio, podemos entender, em parte, como se desenvolveram as disputas por melhores colocações no mercado de trabalho entre nacionais e portugueses, ocasionando o ressurgimento de uma onda de antilusitanismo no Recife. Ao longo desse texto, tentaremos responder alguns questionamentos: Por que a carreira de caixeiro atraía a atenção dos brasileiros pobres? Quais eram as vantagens e desvantagens de se empregar nessa profissão? Quais os caminhos de aprendizado do ofício? Como era o padrão de carreira?

Assim como nas oficinas e manufaturas, os armazéns, lojas e tabernas também abriam suas portas para receber aprendizes interessados em entender da "arte e ciência do comércio", ou, quando muito, a manusear a "vara e côvado". Os empregos de caixeiro disponíveis no comércio eram, em muitos casos, a porta de entrada para muita gente ingressar no mercado de trabalho. Isso porque era quase regra, nesse tipo de empreendimento, o ingresso ainda muito jovem, "rapazola". Para os indivíduos provenientes das camadas pobres, a infância e a adolescência eram periodos importantes na formação para o trabalho. Iniciar como caixeiro era um primeiro passo no mundo do trabalho, pois era o tipo mais comum de aprendizado e ocupação profissional existente para indivíduos livres daquela faixa etária.

É difícil especificar se os recém-chegados nos diversos estabelecimentos comerciais da cidade já iniciavam diretamente como caixeiros. Segundo Jorge Fernandes Alves, a carreira no comércio em Portugal come- 
2

ALVES, Jorge Fernandes. Os Brasileiros: Emigração e Retorno no Porto Oitocentista. Porto: Edição do autor, 1994.

3

MARTINHO, Lenira Menezes. Caixeiros e pés-descalços: conflitos e tensões em um meio urbano em desenvolvimento. In: Negociantes e Caixeiros na Sociedade da Independência. Rio de Janeiro: Secretaria Municipal de Cultura, Turismo e Esportes, Departamento Geral de Documentação e Informação Cultural, Divisão de Editoração, 1993 (Coleção Biblioteca Carioca; v. 24). p.81.

4

Ibidem, p. 39.

5

AZEVEDO, Aluísio. O Mulato. São Paulo: Editora Ática, 1987.

6

CARVALHO, Marcus J. M. de. "O antilusitanismo e a questão social em Pernambuco, 18221848". In: PEREIRA, Miriam Halpern (org.). Actas do Colóquio Internacional sobre Emigração e Imigração em Portugal (Séc. XIX e XX). Portugal/Lisboa: Editora Fragmentos, 1993. p. 154

APEJE (Arquivo Público Estadual Jordão Emereciano), Diário Novo, 22.12.1842, n. 115; Diário Novo, 11.09.1843, n. 195. çava pela entrada como marçano. Esse era um verdadeiro criado para todos os serviços, dependendo dos caixeiros mais velhos do estabelecimento e vivendo permanentemente na casa do patrão. Depois de um longo período de aprendizado, já beirando os 18 a 20 anos, era elevado a caixeiro, podendo mais tarde galgar outros patamares da profissão. ${ }^{2}$

Lenira Martinho mostra que, em muitos estabelecimentos, esses recém-chegados assumiam papéis de responsabilidade equivalentes aos de um adulto. ${ }^{3}$ Ela aponta que, entre os empregados de uma loja, havia os aprendizes, que serviam aos cuidados de outros caixeiros mais experientes, e também os criados de servir, que realizavam tarefas de atendimento ao patrão e a conservação da loja. ${ }^{4}$ Provavelmente, as designações eram distribuidas de acordo com uma determinada hierarquia, onde o iniciante ocupava o patamar mais elementar. É o caso do caixeiro português "Manoelzinho", do romance 0 Mulato de Aluizio de Azevedo, que "por ser o mais novo na casa varria o armazém, limpava as balanças e burnia os pesos de latão"5. Ao principiante era sempre dado o penoso trabalho da limpeza do estabelecimento. Não era à toa que esses meninos eram chamados de "caixeiro vassoura", o caixeiro novato que varria a casa. Marcus Carvalho, estudando os anúncios de trabalho nos jornais do Recife, ressalta que havia uma certa hierarquia funcional etária, sendo em torno de doze anos, ou mesmo antes, o começo do trabalho de caixeiro propriamente dito. Mas, provavelmente, o primeiro emprego seria o de ajudante. ${ }^{6}$

Nas tabernas, botequins, e pequenas lojas de secos e molhados, essas especializações, próprias dos grandes estabelecimentos e firmas comerciais de grosso trato, não deviam ocorrer com freqüência. Podemos dizer que muitos caixeiros, sozinhos, tomavam conta de muitos negócios. Por certo muitos patrões procuravam reduzir ao máximo o número de funcionários assalariados, completando sempre o contingente do estabelecimento com mão-de-obra cativa. É o caso de um botequim denominado "União", localizado na rua dos Quartéis, que, em fins de dezembro de 1842, anunciava precisar de "um bom caixeiro de idade de 12 a 14 anos" e também de "dois moleques que sejam espertos". Em setembro do ano seguinte, o mesmo estabelecimento procurava um "caixeiro diligente" e também um moleque para alugar.7

Ao que tudo indica, escravos também exerciam a caixeiragem. Contudo, não podemos tirar conclusões precipitadas, pois o termo "caixeiro" deveria ser usado também para denominar qualquer indivíduo empregado no comércio. Certamente não devia ser pequeno o número de donos de bodegas e estabelecimentos mais modestos, que, não podendo arcar com os salários de um trabalhador livre, juntava as parcas economias para adquirir pelo menos um cativo e empregá-lo nos serviços de atendimento a clientela. Afinal, para as pessoas que viviam numa sociedade, cujo regime econômico-escravista formou uma cultura da escravidão, possuir escravos era também uma questão de status social. Disso provavelmente não fugiram a regra alguns taberneiros e vendilhões ansiosos para ascender alguns degraus na longa escalada social. Vale destacar que possuir escravos fazia parte do universo simbólico e valorativo daquela sociedade.

Nos jornais pesquisados para esse artigo, não foi verificada a existência de anúncios referentes a escravos classificados no ofício de caixeiro. Contudo, em um processo judicial do antigo Tribunal da Relação de Pernambuco, encontramos um escravo exercendo a função de "caixeiro". Trata-se de um complicado caso de inimizade entre dois proprietários de escravos, em que um é acusado de dar algumas "bengaladas" na escrava do outro. 
IAHGP (Instituto Arqueológico, Histórico e Geográfico de Pernambuco), Apelação Crime (1826-28) - Recife. Apelante: A Justiça. Apelado: Miguel de Souza Fontes (réu seguro). Tribunal da Relação de Pernambuco - 1828, caixa 02.

9

APEJE (Arquivo Público Estadual Jordão Emereciano), Diário de Pernambuco, 01.02.1848, n. 25; Diário de Pernambuco, 28.08.1835, n. 159.

\section{0}

Biography of Mahommah G. Baquaqua. Electronic Edition, http://docsouth.unc.edu/ neh/baquaqua/baquaqua.html.

\section{1}

RIBEIRO, Gladys Sabina. Mata Galego: os portugueses e os conflitos de trabalho na República Velha. São Paulo: Editora Brasiliense, 1990. p. 20.

\section{2}

ALENCASTRO, Luiz Felipe de. Proletários e escravos: imigrantes Portugueses e cativos africanos no Rio de Janeiro, 1850-1872. Novos Estudos - Cebrap, São Paulo, n.21, p.34-35, 1988.

13

APEJE (Arquivo Público Estadual Jordão Emereciano), A Voz do Brasil, 29.01.1848, n. 13; A Voz do Brasil, 17.03.1848, n. 20.
Segundo o agressor, ao entrar tarde da noite em sua casa, viu sair um vulto da penumbra da sala. Tratou logo de arremessar a sua bengala, atingindo em cheio a jovem cativa, que, na ocasião, estava em companhia de um de seus escravos, "caixeiro de sua venda", provavelmente tratando de outros negócios, que não o da venda, em razão do horário e da companhia. ${ }^{8}$

$\mathrm{Na}$ prática, não devem ter sido poucos os escravos que se tornaram caixeiro. Percebe-se que, nos muitos estabelecimentos comerciais que empregavam os dois tipos de mão-de-obra, havia uma divisão um tanto rígida nas funções exercidas por cada empregado. Encontramos referências de uma possivel divisão interna de trabalho nos anúncios colocados por donos de padarias à procura de caixeiro para os seus estabelecimentos. Por exemplo, um anunciante procurava um caixeiro para "vender na sala de uma padaria, cobrar, e entregar pão na rua com um preto". Já uma padaria na rua do Peixoto, nas Cinco Pontas, precisava de "um rapaz para vender pão para o mato com um negro"9. No caso do anúncio citado, provavelmente, quem carregaria o cesto de pão era o escravo, pois, por mais humilde que fosse o trabalhador, não ficaria bem para a sua condição de homem livre executar uma tarefa que atribuída a escravo. Muhommah $\mathrm{G}$. Baquaqua, um africano que publicou, em 1854, uma memória da época em que era cativo, relata a amarga vida que levava quando servia a um padeiro português no Recife. Além de mercadejar pela cidade até as nove horas da noite, recebia diariamente a sua dose de castigo físico. ${ }^{10}$ No caso dos caixeiros e escravos empregados em padaria, provavelmente, os horários de trabalho deveriam ser os mesmos, porém o tipo de atividade e a coação ao trabalho deveriam variar consideravelmente.

Mas, como atesta a historiografia, são os portugueses que dominam o ofício da caixeiragem nas principais cidades do Império. Dominação essa que, junto com o comércio a retalho, formava o que os contemporâneos de ânimos acirrados nos mata-marinheiros chamavam de um verdadeiro monopólio. Segundo Gladys Ribeiro, em se tratando do Rio de Janeiro, esses imigrantes já encontravam um mercado tomado por portugueses, pois seus compatriotas dominavam setores do comércio e as oportunidades de trabalho. ${ }^{11}$ É tamanha a entrada no pais desses trabalhadores destinados ao comércio, que Luiz Felipe de Alencastro coloca-os como uma categoria de relevo na imigração portuguesa, acrescentando, ainda, que esse setor da comunidade lusitana era alimentado por um fluxo regular de imigrantes. ${ }^{12}$

De acordo com a folha nativista $A$ Voz do Brasil, o comércio a retalho pertencente a estrangeiros contava com seis mil lojas espalhadas por toda Província de Pernambuco. Em cada uma dessas casas existia uma média de três ou quatro caixeiros, sendo todos portugueses. No cálculo feito pela folha, que estimava dois portugueses em cada estabelecimento comercial, os números chegavam a assustar: doze mil caixeiros e seus seis mil respectivos patrões, chegando a um total de dezoito mil portugueses. Acrescentava, ainda, que só na rua da Praia, palco dos atentados do dia 26 e 27 de junho de 1848, atuavam mais de "120 marinheiros" no comércio de carne seca, contra apenas 3 brasileiros..$^{13}$

Claro que se deve evitar não só o exagero dessa folha, como também o de tantos outros panfletos nativistas, que viam nesses números uma verdadeira conspiração para dominar o Brasil. Porém, deve-se destacar que era grande o contingente de portugueses dedicado a "caixeiragem" no Recife. Para se ter uma idéia, basta observar o elevado número desses trabalhadores matriculados no Vice-consulado de Portugal entre os anos 


\section{4}

APEJE (Arquivo Público Estadual Jordão Emereciano), Relação dos súditos Portugueses, apresentados e habilitados na Chancelaria do Vice-Consulado de Sua Majestade Fidelíssima nesta cidade e província de Pernambuco. Série Agentes Consulares em Pernambuco. DC-02 (1827-32). Fls. 235-236v. DC-03 (1833-37). Fls. 17-18; 262-266; 269-273v; 276-277v. É interessante perceber que, das " 58 categorias ocupacionais" que aparecem nesses registros, em termos numéricos, depois da ocupação de "caixeiro" (com 508 pessoas), é substancial o número de indivíduos que declaram a ocupação de "marinheiro" (com 153 pessoas devidamente inscritas). Podemos entender, a princípio, esse número elevado de marinheiros devido a situação portuária da cidade do Recife, com seu constante ir e vir de embarcações de outros paises. Entretanto, outro indicativo nos leva a reconsiderar essa afirmativa. Segundo Gladys Sabina Ribeiro, ser marinheiro era um artificio que muitos imigrantes portugueses usavam para pagar a sua passagem até o Brasil. RIBEIRO, Gladys Sabina. A Liberdade em construção: identidade nacional e conflito antilusitanos no primeiro reinado. Rio de Janeiro: Editora: Relume Dumará e FAPERJ, 2002. p. 231. Desta forma, podemos entender que, em virtude de muitos imigrantes não terem ocupação definida, ao desembarcarem no pais, declaravam como ocupação a de marinheiro, haja vista terem, durante o percurso da travessia, trabalhado nessa qualidade, na embarcação, para pagar as despesas de viagem.

\section{5}

CARVALHO, Marcus J. M. de. 0 antilusitanismo e a questão social em Pernambuco, 18221848. In: PEREIRA, Miriam Halpern (org.). Actas do Colóquio Internacional sobre Emigração e Imigração em Portugal (Séc. XIX e XX). Portugal/Lisboa: Editora Fragmentos, 1993. p.149-150.

\section{6}

FREYRE, Gilberto. Sobrados e Mucambos. Rio de Janeiro: Editora Record, 1990. p. 273.

\section{7}

Ibidem. p. 272

18

CARVAlHO, Marcus J. M. de. Op. Cit. p.153.

19

APEJE (Arquivo Público Estadual Jordão Emereciano), Diário Novo, 07.11.1842, n. 79.

\section{0}

0 prévio registro no Consulado Português isentava esse imigrante de um possivel recrutamento. Porém, o que se observa, em alguns casos, é um processo inverso. Muitos portugueses só procediam aos seus registros quando já estavam recrutados, como forma de evitar o cumprimento do serviço militar. de 1831 e 1835: dos 953 "súditos portugueses", 508 (53,3\%) ocupavam a profissão de caixeiro e $445(46,7 \%)$ exerciam outras profissões. ${ }^{14}$

É possivel traçar um perfil desses imigrantes usando não só os anúncios de jornais, mas também a historiografia que trata dos caixeiros e da imigração portuguesa. Geralmente, vinham ainda meninos para o Brasil, atraidos por conterrâneos que formavam uma rede informal de contatos, repassando informações sobre as possibilidades de emprego e até de algum crédito. Na época, o mercado de trabalho era mediado por relações pessoais, onde homens abastados atraiam empregados, muitos até sendo seus parentes. ${ }^{15}$ Isso mostra quão eram importantes as redes de solidariedade nessa sociedade.

$\mathrm{Na}$ expressão de Gilberto Freyre, esses meninos chegavam aqui apenas com o próprio corpo ${ }^{16}$, trazendo, quando muito, uma carta de recomendação. Arrumavam trabalho quase sempre no armazém de um tio, primo, padrinho ou conterrâneo qualquer já estabelecido na cidade. Os laços de parentescos, na maioria das vezes, facilitavam a rápida entrada desses meninos nos empregos do comércio. Nos jornais da primeira metade do século XIX eram freqüentes os anúncios de oferta e procura, que fazem referência a esses caixeiros "recém chegados". Segundo Freyre, eram os "meninos portugueses" os preferidos pelos negociantes para caixeiros de lojas ou armazéns. ${ }^{17}$ Os anúncios de jornais confirmam a preferência, apontada pelos contemporâneos, em empregar esses "pequenos" ou "chegados a pouco" de Portugal no lugar de brasileiros.

Eram os indivíduos moços, destinados ao comércio, que representavam o grosso da imigração lusitana para o Brasil. A pouca idade - em torno de 10 aos 14 anos - muito contava para que fossem admitidos. Para Marcus Carvalho, fica evidente a preferência por esses meninos recém-chegados mais indefesos e facilmente amoldados às práticas do patrão. As expressões como "chegado a pouco", "moderno na terra" e etc, que aparecem em anúncios de caixeiros portugueses, pareciam dizer que esses trabalhadores ainda não tinham o vício da desobediência. ${ }^{18}$ Vício esse que se aprendia na rua, em contato com outros colegas de profissão, longe do olhar do patrão.

Além disso, a preferência por meninos evitava que o negociante contratasse um trabalhador que já tivesse uma familia nuclear estável. Não é a toa que um anunciante, pretendente a caixeiro, avisava que era "homem solteiro e desimpedido de família"19. Na lógica do patrão era mais interessante ter um trabalhador que não dividisse sua atenção e tempo com outros assuntos que não o do estabelecimento. Por isso, a preferência pelos meninos portugueses. Afinal, com a familia no outro lado do Atlântico, restava a eles a dedicação exclusiva ao trabalho, até mesmo como forma de amenizar possiveis saudades dos entes queridos.

Mas não era essa a única vantagem em se ter caixeirinhos lusos nos estabelecimentos comerciais. A nacionalidade estrangeira, o registro no Consulado Português, e, principalmente, a pouca idade tornavam esses caixeiros imunes ao recrutamento. 20 Pela historiografia corrente, sabemos que o recrutamento recaiu em peso sob os brasileiros natos. Muitas vezes, a forma de recrutamento desrespeitava a própria lei reguladora que isentava desse "tributo de sangue" algumas pessoas com ofícios e profissões especificas. Portanto, para um patrão, que poderia ficar a qualquer momento sem a mão-de-obra necessária para o funcionamento do seu estabelecimento, contratar portugueses era mais vantajoso.

Para se perceber como o recrutamento era um empecilho para o trabaIhador nacional, basta analisar rapidamente alguns anúncios, onde os próprios 
21

APEJE (Arquivo Público Estadual Jordão Emereciano), A Voz do Brasil, 15.09.1848, n. 60
22

APEJE (Arquivo Público Estadual Jordão Emereciano), Ofícios do cônsul português Joaquim Baptista Moreira para o Presidente da Provincia Francisco de Carvalho Paes de Andrade. Datados de 11 e 21 de fevereiro de 1832. Fls. 233 e 237-38. Série Agentes Consulares em Pernambuco (1827-32) DC02. Havia um claro conflito nessa questão, pois as instruções para o recrutamento não faziam referência explicita a nacionalidades dos indivíduos recrutados. Isso ficava em aberto, dando margem a interpretações diversas. Ver: Instruções para o recrutamento datada de 10 de junho de 1822, in: APEJE (Arquivo Público Estadual Jordão Emereciano), Diớrio de Pernambuco, 12.08.1835, n. 148, fls. 02-03.

23

APEJE (Arquivo Público Estadual Jordão Emereciano), Ofício do Juiz de Paz suplente José Ignácio da Câmara para o Presidente da Provincia. Datado de 11 de dezembro de 1832. Fl. 392. Série Juiz de Paz (2॰ Semestre de 1832). JP-05. pretendentes a algum trabalho se diziam "desembaraçados" do serviço militar. As reclamações dos recrutados no comércio são muitas. Na ótica dos infelizes que caíam nas malhas do serviço obrigatório, esse sistema era encarado como uma perseguição aos que não tinham protetores influentes.

Também não fugia aos comentários dos nativistas pernambucanos a injustiça do recrutamento. Segundo a folha $A$ Voz do Brasil, teria ocorrido no dia 12 de setembro de 1848 um "tremendo recrutamento" na cidade do Recife, onde não teria escapado ninguém. Inclusive uma pessoa responsável pela distribuição dessa folha teria caído nas garras do serviço obrigatório. Segundo conta a notícia, quando os "caibras" (sic) estavam sendo agarrados na rua, vários portugueses sairam a porta para ver e rir do sucedido. A folha finaliza dizendo que, brevemente, existirá recrutamento para "timbus" (denominação pejorativa aplicada aos portugueses por esse jornal) e também "há de ser engraçado"21.

Porém, nem sempre os lusitanos estavam tão imunes assim de serem vítimas desse "tributo de sangue". É o que nos indica as várias correspondências do Consulado Português em Pernambuco, que fazem referência a "súditos portugueses" recrutados para as tropas de linha e marinha, e para as rondas noturnas na cidade. Talvez, confundidos com os brasileiros natos por falarem a mesma língua ou até, quem sabe, por vingança mesmo, desrespeitando os antigos tratados entre Portugal e o Brasil. Segundo queixa do cônsul português no Recife, um juiz de paz estava recrutando para o "serviço das rondas municipais" vários lusitanos residentes no bairro de Santo Antônio. Mesmo comprovada a nacionalidade portuguesa, o que, por si só, já os isentaria desse serviço, o juiz de paz não se mostrou convencido e ameaçava com prisão os que desobedecessem ao recrutamento. E assim ocorreu com o português Domingos de Araújo, que não teria dado ouvidos às ordens do juiz de paz, quando esse o recrutou para ser "guarda municipal" daquele bairro. Segundo consta no ofício do cônsul, esse súdito português não estaria "nas circunstancia de gozar tal honra", pois "esta distinção só deveria pertencer aos nacionais" (leia-se brasileiros) ${ }^{22}$. A desobediência custou àquele português pelo menos alguns dias de prisão.

Devemos ter em mente que muitos homens usavam todas as estratégias possiveis para se verem livres do recrutamento militar e até dos serviços da Guarda Nacional. 0 caixeiro Antônio Pereira Barros, recrutado para servir à Guarda Nacional, tentou se esquivar dessa obrigação, alegando ao Conselho de Qualificação que seu rendimento salarial era aquém do exigido para fazer parte daquela milícia armada, o que foi confirmado pelo seu patrão João Maria Seve, bem como que era "brasileiro adotivo", português na melhor acepção do termo. Assim, usando essa "evasiva para se livrar do Serviço Nacional", não restou outra saída para o Conselho, a não ser a de dispensar o caixeiro. ${ }^{23}$

A preferência por menores não se justificava apenas pela isenção do recrutamento. Visava também minimizar os custos com o sustento e salários. Os aprendizes de outros ofícios e os iniciados na "caixeiragem" não estavam sujeitos ao recebimento de remuneração. 0 benefício da casa e da comida, em muitos casos, era superior ao salário. Na filosofia da época, o dinheiro era coisa para depois, porque o importante era aprender uma profissão. Assim, casa, comida e aprendizado eram considerados remuneração mais que suficiente pelo esforço da formação.

Em se tratando dos caixeiros portugueses, Luiz Felipe de Alencastro lembra que, geralmente, eles trabalhavam sem remuneração durante um ano 
ALENCASTRO, Luiz Felipe de. Proletários e escravos: imigrantes Portugueses e cativos africanos no Rio de Janeiro, 1850-1872. Novos Estudos - Cebrap, São Paulo, n.21, p.34, 1988.

\section{5}

MARTINHO, Lenira Menezes. Caixeiros e pés-descalços: conflitos e tensões em um meio urbano em desenvolvimento. In: Negociantes e Caixeiros na Sociedade da Independência. Rio de Janeiro: Secretaria Municipal de Cultura, Turismo e Esportes, Departamento Geral de Documentação e Informação Cultural, Divisão de Editoração, 1993 (Coleção Biblioteca Carioca; v. 24). p. 84.

26

Ibidem, p. 85.
FREYRE, Gilberto. Sobrados e Mucambos. Rio de Janeiro: Editora Record, 1990. p. 277. para reembolsar as despesas do transporte. ${ }^{24}$ Para Lenira Martinho, esses caixeiros menores de idade, recrutados em Portugal, deveriam trabalhar apenas pela moradia e alimentação, durante pelo menos três anos, até adquirirem experiência na profissão. ${ }^{25} \mathrm{~A}$ autora também faz uma aproximação entre as condições de trabalho desses caixeiros vindos de Portugal e a dos indentured servants, trabalhadores brancos que, durante o século XVII e início do XVIII, assinavam contratos, ainda em suas terras de origem, e prestavam serviços sem remuneração no intuito de pagar a passagem. ${ }^{26}$ Se levarmos em consideração as duas legislações imperiais, que versavam sobre a Locação de Serviço (1830 e 1837), podemos dizer que a situação de vários trabalhadores imigrantes, incluindo também muitos caixeiros de comércio, era próxima a dos indentured servants. Isso porque, caso não tivesse como pagar a passagem e os custos de alimentação referentes à viagem para o Brasil, o imigrante negociava alguma forma com o capitão ou com o proprietário da embarcação. No destino final dessa viagem, algum contratante arrematava os serviços desse trabalhador por um determinado tempo.

Acredita-se que muitos caixeiros trabalharam durante anos a fio em muitas casas de comércio a retalho sem receber as retribuições salariais. Essa questão dependia exclusivamente do arbitrio do patrão. Mas podemos dizer que o bom desempenho do caixeiro, mostrando serviço e sendo "diligente" nos negócios da casa, poderia levá-lo a subir no conceito do patrão. Assim, poderia galgar outros patamares na profissão e, quem sabe, receber o primeiro salário.

Mas a ascensão na carreira de caixeiro não se dava de forma rápida. Devido a pouca idade e também aos percalços do aprendizado, podemos afirmar que não se faziam profissionais do dia para a noite. Para um iniciante, era longo o caminho da formação. Para ilustrar bem como se dava essa ascensão, construímos um hipotético padrão de carreira desse ofício, usando não só a historiografia especializada no assunto, mas também diversos documentos que fazem referência aos patamares alcançados por caixeiros.

No começo, logo no primeiro contato com o lugar de trabalho, o recém-chegado era conduzido pelo patrão ou outro funcionário mais antigo a se localizar dentro da loja: arrumar as mercadorias nas prateleiras, varrer o chão, conhecer o processo de conservação dos produtos mais pereciveis e fazer pequenos serviços como garoto de recado. Aos poucos, poderia atender aos clientes de passagem pela loja e ir ocupando, gradativamente, o lugar de caixeiro de balcão. Nessa fase, a coisa mais importante que o caixeiro tinha que aprender era dominar o trato com os fregueses. Essa não era uma matéria das mais fáceis, exigia muita dedicação, conhecimento das medidas e pesos, além de muita paciência para servir aos clientes mais caprichosos.

No entra e sai de clientes, o caixeiro poucas vezes se afastava do balcão. Como lembra o verso de uma modinha transcrito por Gilberto Freyre: "Não posso, meu bem, não posso,/ He impossivel lá ir,/ Que o diabo do balcão/Não me deixa sahir"27. Quase não sobrava tempo para ver a namorada, ou mesmo ter uma vida particular. É por isso que encontramos alguns anunciantes evitando exercer o ofício em vendas. Um moço chegado a pouco do "brigue português Conceição de Maria" desejava arranjar-se como caixeiro de "qualquer ocupação, exceto venda". Mesmo novos na terra, esses trabalhadores já conheciam a exaustiva rotina das casas de varejo. Já um rapaz de idade entre 15 e 16 anos que sabia "ler, escrever e 
APEJE (Arquivo Público Estadual Jordão Emereciano), Diário Novo, 16.09.1842, n. 39; Diário Novo, 20.10.1842, n. 66.

29

SETTE, Mário. Maxambombas e Maracatus. 4a edição. Recife: Fundação de Cultura Cidade do Recife, 1981 (Coleção Cidade do Recife; vol. XIX). p. 32.

30

FREYRE, Gilberto. Sobrados e Mucambos. Rio de Janeiro: Editora Record, 1990. p. 276-277.

31

MARTINHO, Lenira Menezes. Caixeiros e pés-descalços: conflitos e tensões em um meio urbano em desenvolvimento. In: Negociantes e Caixeiros na Sociedade da Independência. Rio de Janeiro: Secretaria Municipal de Cultura, Turismo e Esportes, Departamento Geral de Documentação e Informação Cultural, Divisão de Editoração, 1993 (Coleção Biblioteca Carioca; v. 24). p. 40.

32

SETTE, Mário. Op. Cit. p. 27.

33

FREYRE, Gilberto. Op. Cit. p. 271. contar perfeitamente" e tinha até "algumas luzes do comércio" se oferecia para caixeiro de loja de fazendas, caixeiro de rua ou "outra arrumação exceto venda"28.

Se largava o balcão, era para demonstrar as habilidades de atrair 0 interesse das pessoas que passavam nas ruas para dentro das lojas. Nesses momentos, os traços de timidez ficavam de fora, pois era necessária certa desenvoltura. Na briga pela clientela, muitos caixeiros e negociantes acabavam discutindo e, por vezes, iam às vias de fato, trocando socos e pontapés com seus oponentes. Um cronista pernambucano referindo-se ao refinamento que tinha chegado algumas ruas do comércio recifense, lembrava que somente em ruas como a do Queimado, do Rangel e Livramento, "ainda se punham caixeiros às portas agarrando os fregueses matutos" que desembarcavam nas Cinco Pontas. ${ }^{29}$

Os caixeiros levavam uma vida difícil, sujeita a toda sorte de acontecimentos. Além de trabalhar todos os dias da semana (muitas lojas abriam no domingo pela manhã), não tinham um horário de trabalho fixo. Gilberto Freyre, citando um artigo publicado em 1835, no jornal carioca 0 Defensor do Comércio, diz que a caixeiragem não estava livre da labuta nem nos domingos e dias santos. Nem para ouvir missa eram liberados do balcão. ${ }^{30}$ Estavam sujeitos a todos os tipos de imprevistos, como embalar e desembalar mercadorias até altas horas da noite e etc.

Para cumprir tamanha carga horária era necessário morar no próprio estabelecimento comercial. Na época, era comum o local de trabalho servir também de moradia. Muitos dormiam entre as mercadorias do depósito ou no sótão dos sobrados e faziam suas refeições nos balcões, onde, durante o expediente de trabalho, atendiam aos clientes. As refeições nos locais de trabalho evitavam possiveis dispersões.

0 beneficio da moradia e alimentação trazia vantagens tanto para o funcionário, que não despenderia seu salário em outros gastos, como também para o patrão. Além da vigilância cerrada no funcionamento da casa, o patrão também podia contar com os serviços do caixeiro a qualquer hora da noite para uma possivel emergência. A moradia possibilitava um aumento na exploração da força de trabalho. As vendas, tabernas e lojas, como extensão da casa do patrão, tinham algumas regras de condutas, onde o respeito e a obediência faziam parte da cartilha dos empregados. Segundo Lenira Martinho, as condições de trabalho e moradia refletiam a própria forma como se organizava o trabalho, que se aproximava mais de uma forma de trabalho doméstico. ${ }^{31}$

Viver junto do patrão não era tarefa das mais fáceis. 0 aprendizado na profissão era rigoroso e os castigos disciplinares eram uma prática comum, ainda mais, em se tratando de caixeiros menores, vistos como "filhos" que deviam obediência aos patrões investidos de "pais" pela ótica paternalista. Assim, qualquer desvio de conduta era punido com severidade. Mário Sette lembra que o "côvado de madeira" usado pelos vendedores de tecido para medir o comprimento da peça servia também para "exemplar os caixeiros"32. Não é à toa que Gilberto Freyre chega a dizer que muitos eram "quase escravos louros"33, tamanha eram as privações que passavam e os mais diversos tipos de coação para o trabalho a que estavam submetidos. Para alguns desses caixeiros, a presença constante do patrão nas suas vidas não representava conforto algum. É de se imaginar que, na pouca história de vida desses meninos, o abandono e os maus tratos deveriam ser uma constante. 
34

IAHGP (Instituto Arqueológico, Histórico, Geográfico Pernambucano), Apelação Crime vinda do juizo de fora desta cidade - (1827- 28) - Recife. Apelante: o réu Antônio Martins do Couto Vianna. Apelado: o autor João Marques da Trindade. Tribunal da Relação de Pernambuco - 1828, caixa 01

35

IAHGP (Instituto Arqueológico, Histórico, Geográfico Pernambucano), Diário Novo, 03.01.1848, n. 01.
Mas, apesar de tudo, era ainda perto do patrão que se encontravam seguros. Nos momentos de apuro, os empregados poderiam contar com o patrão. Um bom exemplo disso ocorreu na rua de Madre Deus, na tarde do dia 16 de fevereiro de 1827, quando Antônio Martins do Couto Vianna, comerciante de uma loja de molhados, agride com "bofetadas" e "coices" João Marques Trindade, caixeiro de 14 anos da loja defronte a sua, que também negociava com os mesmos gêneros. 0 patrão do jovem agredido toma suas dores. Afinal, seu caixeiro era uma pessoa de "bons costumes" que, para "adquirir meios de vida", empregava-se como caixeiro de sua loja, onde procedia com "humildade, fidelidade e mansidão". Completava seu depoimento dizendo que dava "boa educação a sua família, e aos que estão de baixo da sua inspeção", no caso, seu caixeiro. ${ }^{34}$

Conquistada a confiança do patrão, poderia ser promovido a caixeiro de fora. Sendo obrigado a ganhar as ruas da cidade, seus serviços eram muitos: levar títulos e letras para cobrar a clientes do seu patrão, ir até a alfândega tratar da burocracia do despacho e recepção de mercadorias e entregar alguma encomenda de maior responsabilidade. Nos estabelecimentos mais modestos, cabia a esses caixeiros a venda de produtos pelas ruas, à moda dos antigos mascates. Chegar a condição de caixeiro de fora significava que esse funcionário atingiu sua maturidade profissional. Mas, em alguns momentos, tamanha confiança sofre abalos. É o que ocorre com um caixeiro incumbido de vender pão e bolacha na cidade de Olinda. Após abandonar a padaria onde trabalhava, localizada nas Cinco Pontas do Recife, esse caixeiro não prestou contas do dinheiro que alguns fregueses ainda deviam ao estabelecimento. Conforme recomendava o dono da padaria aos demais comerciantes e fregueses da cidade, esse procedimento tornava esse caixeiro "incapaz da confiança de qualquer pessoa"35. Não é por outro motivo que é quase regra, nesses anúncios, a exigência de um "fiador" ou o "conhecimento da conduta" do requerente ao emprego, justamente para evitar futuros aborrecimentos.

Deve-se levar em conta que as regras costumeiras de um mercado de trabalho escravo difundiram-se por todas as relações sociais e se estenderam também às pessoas livres, que procuravam trabalho na cidade. Como bem sabemos, um escravo que trabalhava alugado a terceiros só podia ser aceito com segurança quando seu comportamento fosse referendado por alguém com autoridade suficiente, como o seu dono, que servia de fiador. Esse tipo de conduta continuou até depois do fim da escravidão. Esse sistema de "fiança" também era exigido aos trabalhadores livres. Para se conseguir entrar no mercado de trabalho, trabalhar dentro da casa de algum comerciante ou executar serviços com certa independência do patrão, era necessário que esse empregado tivesse alguém que afiançasse a sua conduta. Era nesse misto de desconfiança que começaram muitas relações entre trabalhadores e patrões.

0 bom relacionamento entre patrões e caixeiros era fundamental tanto para o sucesso da empreitada comercial, como também para a ascensão profissional do empregado. Para isso muito contava a história de vida do patrão. Muitos comerciantes das praças do Recife e outras capitais começaram suas carreiras como caixeiro. A vida ascética e o trabalho morigerado fizeramnos progredir e alcançar novos padrões de vida. Tornavam-se, assim, fonte de inspiração para os seus caixeiros, ansiosos por ascenderam socialmente. Estava no imaginário desses caixeiros a idéia de ascensão social através do trabalho. Vale lembrar que esses caixeiros recém-chegados iam aprendendo a ver o mundo pela ótica do patrão. 


\section{6}

MARTINHO, Lenira Menezes. Caixeiros e pés-descalços: conflitos e tensões em um meio urbano em desenvolvimento. In: Negociantes e Caixeiros na Sociedade da Independência. Rio de Janeiro: Secretaria Municipal de Cultura, Turismo e Esportes, Departamento Geral de Documentação e Informação Cultural, Divisão de Editoração, 1993 (Coleção Biblioteca Carioca; v. 24). p. 39.

37

RIBEIR0, Gladys Sabina. Mata Galego: os portugueses e os conflitos de trabalho na República Velha. São Paulo: Editora Brasiliense, 1990. p. 21.

38

FREYRE, Gilberto. Sobrados e Mucambos. Rio de Janeiro: Editora Record, 1990. p. 277.

\section{9}

GRAHAM, Maria. Diário de uma Viagem ao Brasil (e de uma estada nesse pais durante parte dos anos de 1821, 1822 e 1823). Londres, 1824; reedição: São Paulo: Companhia Editora Nacional, 1956. p. 137.
Então, identificar-se com os interesses da casa era o primeiro passo para o caixeiro atrair a atenção do patrão. Isso leva a crer que, tamanho zelo pelos negócios da casa, levavam os empregados a se sentirem praticamente sócios do patrão. Os patrões aproveitam a ocasião para deixar praticamente tudo a cargo dos caixeiros. Por vezes, encontramos anúncios em que caixeiros tomam a frente das vendas da loja, promovendo o crescimento dos negócios de seu patrão. Lenira Martinho aponta que quase sempre os caixeiros estavam efetivamente a frentes dos negócios das lojas, fazendo compras, realizando pagamentos e recebendo contas. Essa dependência tinha um quê de despreparo do patrão em relação aos mecanismos de escrituração, pois freqüentemente não sabiam nem ler nem escrever. ${ }^{36}$

Se identificar com os interesses do patrão, ser diligente nos trabalhos e digno de confiança era o início para garantir uma futura sociedade. Esse caixeiro se tornaria, a longo prazo, um representante direto do patrão. Era essa mais uma forma de se beneficiar do caráter paternalista da relação patrão-empregado predominante nos pequenos estabelecimentos comerciais. Para Gladys Ribeiro, esse tipo de relação impossibilitava a existência de conflitos entre os imigrantes portugueses no mundo do trabalho. "A perseguição da autonomia e da liberdade levava os empregados portugueses a se deixarem paternalizar pelos patrões ou a se solidarizarem com os seus objetivos. De acordo com a ideologia do trabalho, patrões e empregados são vistos como iguais. Esta igualdade exerce um papel ideológico importante e legitima o contrato desigual de trabalho"37.

É certo que a dedicação exclusiva aos negócios do patrão tinha as suas vantagens. Uma delas seria uma possivel sociedade, a qual, muitas vezes, realizava-se através do matrimônio com a filha do patrão. Como lembra Freyre, muitos caixeiros arrumaram esposas sem sair do ambiente de trabalho. Filhas, sobrinhas ou afilhadas de seu patrão eram desposadas. ${ }^{38} \mathrm{Em}$ seu diário de viagem, a inglesa Maria Graham faz menção a esse tipo de questão: "Os portugueses europeus ficam extremamente ansiosos por evitar o casamento com os naturais do Brasil e preferem antes dar suas filhas e fortunas ao mais humilde caixeiro de nascimento europeu do que aos mais ricos e meritórios brasileiros"39. Alguns chegaram até a constituir união com as viúvas de seus patrões, quando esses faleciam. Esse tipo de união evitou, muitas vezes, que os negócios e a família do falecido patrão ruissem por inteiro ante a ausência de um braço masculino para tocar o estabelecimento. Eram nesses momentos que muitos caixeiros subiam ao patamar de sócio e patrão.

Mas nem todos tinham a sorte de entrar para a família do patrão. Para muitos empregados, a ascensão na carreira de caixeiro era obtida através do próprio esforço. Quando muito, contavam com a ajuda do patrão e de outros funcionários mais espertos do estabelecimento, capazes de ensinar os tortuosos caminhos da ascensão profissional.

0 verdadeiro salto na "caixeiragem" dependia do porte da empresa e de uma certa escolaridade. Ocupar a vaga de caixeiro de escritório era o patamar mais alto da profissão. Era exigido um prévio conhecimento de contabilidade, uma vez que se ficava responsável pela parte financeira e pela correspondência de créditos e escrituração. Se a empresa negociasse com o exterior, era imprescindivel que esse caixeiro dominasse uma língua estrangeira. Em se tratando dos caixeiros das casas de grosso trato do Recife, era fundamental o conhecimento de outros idiomas, como o francês e o inglês. Afinal, em uma cidade portuária e cosmopolita como o Recife, negociava-se em quase todas as línguas. 
40

MARTINHO, Lenira Menezes. Caixeiros e pés-descalços: conflitos e tensões em um meio urbano em desenvolvimento. In: Negociantes e Caixeiros na Sociedade da Independência. Rio de Janeiro: Secretaria Municipal de Cultura, Turismo e Esportes, Departamento Geral de Documentação e Informação Cultural, Divisão de Editoração, 1993 (Coleção Biblioteca Carioca; v. 24). p. 53.

41

APEJE (Arquivo Público Estadual Jordão Emereciano), Relatório que a Assembléia Legislativa de Pernambuco apresentou na sessão ordinária de 1839 o exmo Presidente da mesma Província Francisco do Rego Barros. Pernambuco: Typographia de Santos \& Cia, 1839, pp. 06-07.

42

MARTINHO, Lenira Menezes. Op. Cit. p. 53.

43

IAHGP (Instituto Arqueológico, Histórico, Geográfico Pernambucano), Diário Novo, 05.09.1845, n. 196; Diário Novo, 25.11.1845, n. 261.
Porém, a situação de um aprendizado formal do comércio, onde os iniciantes estudariam contabilidade, aprenderiam a fazer cálculos de juros e ter noção de títulos e garantias de créditos, entre outros conhecimentos, estaria muito longe de ser uma realidade para muitos caixeiros. Era esse tipo de educação que possibilitaria ao caixeiro dar um verdadeiro salto na profissão.

Pelo menos no Rio de Janeiro, os caixeiros tiveram oportunidade de receber uma educação profissional através das chamadas "Aulas de Comércio". Essas aulas foram criadas pela iniciativa do Estado, logo após a chegada de Dom João $\mathrm{VI}$, seguindo uma orientação de ensino herdado de Portugal, onde primeiramente foram fundadas durante a administração pombalina (1750-1777), dentro do espírito da época de elevar o status do comerciante e de melhorar as condições do comércio nacional. Porém, estavam excluídos dessas aulas os comerciantes a retalho, os de "vara e côvado". Essas aulas tinham o intuito de equiparar, em conhecimentos e habilidades, o caixeiro nacional ao caixeiro estrangeiro. ${ }^{40}$ Lembremos que o comércio não era uma disciplina acadêmica, mas sobretudo prática, um métier. Essas aulas eram uma tentativa de transformar essa prática num saber especifico.

Sabe-se que, no Recife, o Liceu tentou introduzir esse tipo de ensino nos quadros da instituição, mas não obteve sucesso. Segundo um Relatório do Presidente da Província, Francisco do Rego Barros, de 1839, houve uma tentativa de promover um concurso para arregimentar profissionais qualificados para ensinar a chamada "Cadeira de Comércio". Mas o resultado não foi dos mais animadores, pois apareceu apenas um concorrente e o concurso foi suspenso no último momento. 0 problema não estava no único concorrente que apareceu, que, por sinal, era "habilitado com exames da Aula de Comércio de Lisboa", mas sim no fato de "não haver pessoas idôneas para julgar do seu mérito absoluto". Não se conhecia nem ao menos os pontos que deveriam constar nos exames de seleção dessa cadeira. ${ }^{41}$

Para os caixeiros das bodegas, tavernas e demais comércios a retalho, que em tese estavam excluídos dessas "Aulas do Comércio", restavam outros caminhos. Segundo Lenira Martinho, existia uma "considerável oferta" de aulas e mesmo cursos particulares de escrituração mercantil no Rio de Janeiro. ${ }^{42}$

Nos jornais do Recife também encontramos anúncios que fazem referência a atuação de professores, na sua grande maioria, dedicados ao ensino das "primeiras letras". Era no ramo da educação que muitas mulheres tiravam sua sobrevivência, trabalhando no delicado aprendizado de meninos e meninas, filhos de pais que pudessem pagar por esse tipo de serviço. Fora as "primeiras letras", existiam os chamados "cursos preparatórios", que, como o nome indicava, era responsável pela preparação dos filhos de pais abastados, desejosos em os verem ingressar no curso jurídico, elevando quem sabe o status social da família.

Porém, nem sempre esse caminho era seguido a risca pelos alunos que freqüentavam esses cursos preparatórios. As exceções aparecem aqui e ali na documentação. A exemplo disso, encontramos um anúncio de um "moço de vinte anos" que resolveu fazer o caminho inverso. Depois de ter cursado "três preparatórios", latim, francês e geometria, decidiu entrar para o comércio, oferecendo-se como "caixeiro de rua ou de escrita". Em um outro anúncio, encontramos um moço "de boa letra" e que "escreve correto", tendo "quase todo o curso preparatório", se oferecer para fazer escrituração em casa de comércio. ${ }^{43}$ Lembremos que muita gente cursava esses 
44

APEJE (Arquivo Público Estadual Jordão Emereciano), Diário Novo, 12.04.1843, n. 83.

45

HOLANDA, Sérgio Buarque de. Raizes do Brasil. Rio de Janeiro: Editora José Olympio, 11a edição, 1977. p. 50-51.

\section{6}

FREYRE, Gilberto. Sobrados e Mucambos. Rio de Janeiro: Editora Record, 1990. p. 276. Segundo Lenira Menezes Martinho, nos compêndios de comércio da primeira metade do século XIX, a profissão de caixeiro era bastante valorizada. Autores embebidos pelo liberalismo europeu estavam interessados em conceder melhor status às atividades mercantis vinculando o principio liberal de que só o comércio enriquece uma nação. Para esses autores de compêndios sobre o comércio, só o conhecimento preciso de escrituração e das operações de crédito levariam o comércio pátrio a se equiparar aos das nações por eles consideradas mais adiantadas, como a Inglaterra e a França. MARTINHO, Lenira Menezes. Caixeiros e pés-descalços: conflitos e tensões em um meio urbano em desenvolvimento. In: Negociantes e Caixeiros na Sociedade da Independência. Rio de Janeiro: Secretaria Municipal de Cultura, Turismo e Esportes, Departamento Geral de Documentação e Informação Cultural, Divisão de Editoração, 1993 (Coleção Biblioteca Carioca; v. 24). p. 38.

\section{7}

APEJE (Arquivo Público Estadual Jordão Emereciano), Diário Novo, 07.10.1842, n. 55.

\section{8}

MURILO DE CARVALHO, José. A construção da ordem: a elite política imperial. Rio de Janeiro: Campus, 1980. p. 65. "preparatórios" mas nem sempre optavam por ingressar na faculdade de direito, não fazendo as provas de admissão. Alguns também não foram bem sucedidos nos exames. Além do mais, para ingressar no curso jurídico, era necessário que o candidato tivesse alguém para Ihe sustentar no período em que cursava a faculdade.

Mas, pelo menos na cidade do Recife, não encontramos muitos professores dispostos a ensinar os tortuosos caminhos do aprendizado comercial. Conta-se nos dedos os anúncios de professores que se propõem a ensinar matérias especificas para a vida comercial. Os exemplos são raros, porém, interessantes, pois nos dão uma idéia do que era fundamental aprender para galgar patamares maiores na profissão de caixeiro. Uma pessoa apta anunciava no Diário Novo "ensinar álgebra, aritmética, geometria elementar, e escrituração comercial bem como toda contabilidade, necessária ao comércio; advertindo que ensinar-se-ão todas estas matérias, ou cada uma delas em particular, tanto em casa da pessoa, que se oferece como na dos indivíduos, que quiserem aprendê-las"44.

Mesmo que existissem em demasia esses professores, provavelmente a formação para o comércio não atraía o interesse das pessoas que podiam arcar com as despesas desse aprendizado. Como lembra Sérgio Buarque de Holanda, a mentalidade senhorial, que invadiu os sobrados das principais cidades oitocentistas brasileiras, achou nas atividades políticas, burocráticas e nas profissões liberais um lugar perfeito para o seu exercicio. ${ }^{45}$ Os cursos juridicos de Olinda e São Paulo atraíam a fina flor da elite nacional, ciosa em reforçar ainda mais o chamado "culto ao bacharelismo". Portanto, os conhecimentos das matérias referentes ao comércio, que formariam caixeiros, guarda-livros e futuros comerciantes, não atraiam o interesse dos que podiam pagar.

Para reforçar o argumento acima, Gilberto Freyre lembra que os brasileiros nascidos ricos desprezavam não só os ofícios mecânicos, relegados a europeus e escravos, como também as atividades do comércio. Inteiramente desconsideradas, as profissões de caixeiro e guarda-livro estavam muito abaixo da hierarquia dos bacharéis e doutores. 46

Dando uma boa olhada nos jornais do século XIX, um anúncio nos chama a atenção. Escrito por um certo Emilio Xavier Sobreira de Magalhães, que recebia alunos em sua casa na rua de Santa Thereza. Esse professor se propunha a ensinar a "ler, escrever e contar" (requisitos básicos encontrados nos muitos anúncios de caixeiros), como também "Gramática Portuguesa e Doutrina Cristã" pelo "módico preço de 2000rs. mensais". Além do mais, propunha-se a ensinar "gratuitamente aos filhos das pessoas que por sua pobreza não podem pagar", contanto que apresentassem "documento que prove essa pobreza, e a boa conduta do menino"47. Pela singularidade desse anúncio, podemos afirmar que, para os que não tinham posses, a educação formal era um luxo que nem todos podiam arcar. José Murilo de Carvalho, utilizando dados de um censo de 1872, diz que apenas 16\% da população entre 6 e 15 anos freqüentava escola. 48 Provavelmente, esse número diminuiria em se tratando da primeira metade do século XIX. Eram essas algumas das dificuldades que impossibilitavam os nacionais estarem aptos para exercer a caixeiragem nas grandes firmas mercantis de grosso trato.

Para a grande maioria das familias pobres era mais interessante ter seus filhos empenhados em aprender numa oficina ou num estabelecimento comercial, do que numa escola, mesmo porque o parco salário que, por acaso, viessem a receber reforçaria o orçamento e ajudaria em muito na manutenção do lar. Assim, para os caixeiros advindos de famílias sem recursos algum, 
FREYRE, Gilberto. Sobrados e Mucambos. Rio de Janeiro: Editora Record, 1990. p. 271.

50

APEJE (Arquivo Público Estadual Jordão Emereciano), Diário de Pernambuco, 09.05.1836, n. 101.

51

AALPE (Arquivo da Assembléia Legislativa de Pernambuco), Petição enviada pela Câmara Municipal da cidade de Espírito Santo (Pau d'Alho), ao Presidente da Assembléia Provincial, Franklin Américo de Menezes Dória. Datado de 25 de fevereiro de 1881. Fls. s/n. Série Petições, Caixa 146, ano de 1881.

52

AALPE (Arquivo da Assembléia Legislativa de Pernambuco), Petição encaminhada aos Deputados da Assembléia Provincial de Pernambuco pelos caixeiros do comércio da cidade de Goiana. Datado de 13 de abril de 1881 Fls. s/n. Série Petições, Caixa 146, ano de 1881.

53

APEJE (Arquivo Público Estadual Jordão Emereciano), A voz do Caixeiro, 22.05.1890, n. 01. o aprendizado se dava no dia-a-dia de trabalho, no contato direto com os problemas do estabelecimento. Como lembra Gilberto Freyre, a formação de muitos caixeiros se fazia dentro do próprio lugar de trabalho. 49

Mas não só a falta de recursos impossibilitava um aprendizado formal. 0 tempo também se colocava contra esses caixeiros. A jornada de trabalho era longa e, no caso dos que trabalhavam nas muitas tabernas existentes no Recife, o trabalho entrava noite adentro, restando pouco tempo para qualquer atividade extra. Por mais que as autoridades públicas tentassem, por meio de editais, proibir não só o funcionamento das tabernas, como também a circulação de escravos "depois do toque de 9 horas da Matriz"50, isso quase nunca era cumprido.

Provavelmente, essa situação poderia ser tolerada caso o caixeiro tivesse participação nos lucros, ou tivesse em vista uma futura sociedade com seu patrão, ou mesmo vivesse uma situação de total dependência em relação ao dono do estabelecimento. Mas podemos dizer que nem sempre as coisas permaneceram dessa forma. Em 1881, a Câmara Municipal de Pau d'Alho enviava uma petição a Assembléia Provincial pedindo uma "urgente medida" para sanar o sofrimento dos caixeiros e demais empregados do comércio daquela localidade. Queriam a aprovação de algumas "posturas adicionais" visando proporcionar algum descanso ou momentos de folga para esses trabalhadores. Segundo ressaltava o documento, solicitavam que os estabelecimentos comerciais fechassem, com exceção das boticas, aos domingos e dias santos e que as lojas de secos e molhados e padarias fechassem suas portas às duas horas da tarde. Pedia, ainda, que fossem punidos com multa de "trinta mil réis" os estabelecimentos que desrespeitassem essas posturas. Afinal, o "árduo trabalho de mercadejar de manhã à noite, nos Domingos e Dias Santos de guarda" levavam não só ao "menoscabo da religião" como também a "ruina da saúde d'aqueles aos quais a pobreza os leva a suportar tais serviços"51.

Da mesma forma também protestavam os caixeiros da cidade de Goiana. Em uma petição recheada de assinaturas encaminhada à Assembléia Provincial, esses trabalhadores pediam a criação de uma postura que conservasse os estabelecimentos comerciais fechados nos Domingos e Dias Santos. Sustentavam seu argumento, dizendo que "todas as classes gozam de descanso n'aqueles dias" menos os caixeiros de comércio. Conforme prosseguiam sua reclamação, a eles era vetado o tão conhecido "preceito evangélico" que dizia "descansarás no sétimo dia". Afinal, depois de "seis dias de laborioso trabalho", não tinham direito a repouso nem a algum tempo livre para poder "empregar em alguns estudos" no intuito de adquirir instrução. 52

É interessante perceber que a questão das horas de trabalho vai aparecer como uma das primeiras reivindicações dos trabalhadores do comércio. Em 1890, entrava em circulação no Recife o jornal $A$ voz do Caixeiro que, já no seu editorial, avisava que tinha o intuito de servir a causa da "classe caixeiral", no reconhecimento de alguns dos seus direitos. Um desses direitos que estava em pauta era referente à jornada de trabalho. Segundo esse jornal, era necessário restringir o número de horas de trabalho para um periodo mais compatível com as "exigências da saúde". Essa era uma das aspirações das "classes operárias" que, em toda Europa, procuravam estabelecer "como máximo de trabalho diário" o período de oito horas. 53

Ainda segundo esse jornal, durante muito tempo, o caixeiro do comércio a retalho estava obrigado a uma jornada de trabalho de quinze horas diárias. Porém, mesmo com a recente diminuição da carga horária de quinze para doze 
54

APEJE (Arquivo Público Estadual Jordão Emereciano), A voz do Caixeiro, 22.05.1890, n 01; A voz do Caixeiro, 23.06.1890, n. 05.

55

APEJE (Arquivo Público Estadual Jordão Emereciano), Diário Novo, 31.08.1842, n. 26

\section{6}

LPEH-UFPE (Laboratório de Pesquisa e Ensino de História da Universidade Federal de Pernambuco), Diário de Pernambuco, 04.02.1848, n. 27.

\section{7}

LPEH-UFPE (Laboratório de Pesquisa e Ensino de História da Universidade Federal de Pernambuco), Diário de Pernambuco, 01.03.1845, n. 49.

\section{8}

APEJE (Arquivo Público Estadual Jordão Emereciano), Diário de Pernambuco, 23.03.1837, n. 67.

\section{9}

IAHGP (Instituto Arqueológico, Histórico, Geográfico Pernambucano), Diário Novo, 24.07.1848, n. 159.

\section{0}

RIBEIRO, Gladys Sabina. Mata Galego: os portugueses e os conflitos de trabalho na República Velha. São Paulo: Editora Brasiliense, 1990. p. 21. horas, em virtude da obrigatoriedade de se fechar as portas dos estabelecimentos comerciais às seis horas da tarde, esse jornal lembrava que esse direito ainda não era um privilégio da "quase totalidade do comércio". Muitos caixeiros estavam subordinados a um horário que ia das 6 da manhã às 9 horas da noite, chegando a um total de 17 horas de trabalho diário. 54

Quase não sobrava tempo livre para que esses caixeiros se dedicassem a outras atividades. Muitos aproveitavam os raros momentos de folga para aprender mais sobre a profissão. Outros aproveitavam o tempo livre para descansar ou para algum tipo de lazer.

Portanto, tudo tinha que ser aprendido no âmbito do estabelecimento comercial, observando o movimento dos outros trabalhadores e se inteirando nos negócios da casa. Não é a toa que muitos anúncios pedem meninos, rapazes e moleques que sejam "espertos". Afinal, ninguém quer perder muito tempo ensinando os tortuosos caminhos de uma profissão.

Podemos ter em mente que muitos conflitos de trabalho foram gerados a partir do desequilíbrio de qualificações. A falta de escolaridade era um dos grandes problemas que impossibilitava a ascensão dos brasileiros na profissão de caixeiro. Isso pode ser percebido pela sinceridade de alguns anunciantes. Um rapaz brasileiro de 23 anos, que se oferecia para ser caixeiro de engenho, avisava que sabia "ler e escrever sofrivelmente" 55 . Em contrapartida, encontramos alguns anúncios de trabalhadores europeus recheados de atributos profissionais. Como um rapaz que estava sendo anunciado mesmo antes de sua chegada da Europa. Segundo o anúncio, o rapaz tinha "boa educação", sabia "inglês, francês e alemão" e pretendia se empregar em um escritório. ${ }^{56}$ Outro, "um moço de 18 anos, chegado há pouco de Portugal, filho de pais estrangeiros," oferecia-se para caixeiro de rua, escritório. Segundo definia-se, era "bem educado", falava e escrevia "muito bem francês e italiano"57. Já um português que se oferecia para "caixeiro de escrituração" sabia "bem ler, escrever e contar", conhecia a língua francesa e tinha "aprovação d'Aula de comércio"58.

Porém, não podemos tirar conclusões precipitadas apenas pelos anúncios. Afinal, o intuito era ser admitido e valeria exagerar nos atributos profissionais. Além do que, mesmo que de forma bastante modesta, existiam anúncios de trabalhadores brasileiros com excelentes qualificações. Por exemplo, um rapaz brasileiro de 19 anos, "com bastante habilidade" e que "fala e traduz francês", oferece-se para caixeiro de "escritório ou de cobrança"59.

Para Gladys Ribeiro, não era a condição especifica do indivíduo, isto é, ser ou não ser mão-de-obra especializada, que o situava no mercado de trabalho. Os laços familiares, de solidariedade e de origem, entre outros, desempenham um papel importante na sua integração na nova sociedade. ${ }^{60}$ Contudo, essa afirmativa não fecha toda a questão. Como explicar os diversos anúncios em que tanto comerciantes estrangeiros, como nacionais, procuram por meninos portugueses para empregar em seus estabelecimentos? A resposta pode estar também no grau de instrução desses menores.

Um estudo sobre a emigração no Alto-Minho, província de Portugal, constata que grande parte da imigração se constituía de indivíduos alfabetizados, onde muitos apresentavam um invejável grau de cultura, que contraria em muito uma velha corrente de estudiosos que afirmava que o emigrante português é sinônimo de ignorância. Entre os anos de 1836 e 1847, as saidas para o Brasil eram somente de pessoas que sabiam ler, escrever e contar. Constatou-se, ainda, que, até 1850, quanto mais novos os imigrantes, mais notório era o seu preparo na arte de "ler, escrever e contar", 
61

RODRIGUES, Henrique. Emigração e Alfabetização: 0 Alto-Minho e a Miragem do Brasil. Viana do Castelo (Portugal): Edição financiada pelo Governo Civil de Viana do Castelo, 1995. p. 80-81.

62

Ibidem, p. 81. qualificações fundamentais para o exercício da caixeiragem. Interessante nesse estudo foi perceber que em algumas freguesias, onde mostrava um alto índice de emigrantes alfabetizados, não existiam estabelecimentos de ensino oficial. Assim surgiu a necessidade nessas freguesias de incrementar escolas particulares com o objetivo de oferecer, aos futuros emigrantes, algumas "habilitações" para o desempenho de atividades de apoio ao comércio, geralmente como "caixa"61. Isso leva a crer que boa parte da instrução era financiada pela própria família do imigrante.

É tanto o interesse por essas "habilitações" que não passa despercebido aos olhos das autoridades públicas. Um relatório sobre o "Estado da Administração Pública nos Districtos (sic) Administrativos do Continente do Reino e llhas Adjacentes" é bem elucidativo quanto a questão da preparação de trabalhadores para o comércio, valendo a pena ser transcrito:

\footnotetext{
A instrução pública, se não tem n'este distrito o desenvolvimento que era mister, não pode dizer que esteja em mais atraso do que em outros pontos do paiz (sic). Sendo excessiva aqui a população, e possuídos como se acham os povos da mania da emigração, todos os annos sae (sic) um numero bastante avultado de rapazes que vão procurar no Brasil uma posição que difficilmente (sic) alcançariam se ficassem na sua Pátria; e estes rapazes, destinados quase todos a ser empregados como caixeiro nas casas de comercio d'aquelle (sic) Império, precisam de ir habilitados com os conhecimentos de ler escrever e contar, indispensáveis para poderem abraçar a profissão a que seus paes (sic) os dedicam. Talvez por estes sejam bastante freqüentadas as escolas de ensino primário (...). 62
}

As familias instruiam seus filhos, desde a tenra idade, com determinadas habilitações, para, em seguida, enviarem-nos ao Brasil. Esses eram alguns dos imigrantes que aportavam nas cidades brasileiras para competir com os nacionais pelas melhores oportunidades de trabalho. Obviamente, também eram os preferidos pelos comerciantes de um modo geral.

Assim, o funcionamento interno desses estabelecimentos comerciais, em que jovens imigrantes portugueses ocupavam as vagas de caixeiro, prejudicava a colocação dos brasileiros pobres nesse setor de serviço. Esses imigrantes, provenientes tanto de províncias do interior como das cidades portuárias e até das ilhas atlânticas do Império Português, vinham para o Brasil quase sempre através de uma rede informal de parentesco. Além disso, eram preferidos no mercado de trabalho tanto pela maior escolaridade como também pela pouca idade que tinham, amortizando assim os custos com salários. Pode-se dizer que a imigração portuguesa criou uma comunidade cultural mais fechada no que diz respeito a empregos e a propriedade, o que influenciou diretamente os sentimentos nativistas nos anos quarenta. Conhecendo um pouco mais a vivência desses trabalhadores imigrantes, que vinham do outro lado do Atlântico para tentar a vida nas casas de comércio do Recife, podemos entender em parte aquelas manifestações de rua que perturbaram a capital da Província de Pernambuco durante os anos quarenta do século XIX.
Recebido para publicação em abril de 2007

Aprovado em setembro de 2007 